\title{
Age of the emerald mineralization from the Itabira-Nova Era District, Minas Gerais, Brazil, based on LA-ICP-MS geochronology of cogenetic titanite
}

Idade da mineralização de esmeralda do distrito de Itabira-Nova Era, Minas Gerais, Brasil, com base em geocronologia LA-ICP-MS de titanita cogenética

\author{
Hanna Jordt-Evangelista ${ }^{1 *}$, Cristiano Lana ${ }^{1}$, \\ Carlos Eduardo Reinaldo Delgado ${ }^{1}$, Deiwys José Viana ${ }^{1}$
}

\begin{abstract}
In the Itabira-Nova Era Emerald District, southeast Brazil, gemological emerald is extracted from underground mines found in schist-type deposits at the contact zone of the Archean Metavolcanosedimentary Sequence of the Guanhães Complex and Paleoproterozoic anorogenic granites of the Borrachudos Suite. Schist-type deposits are commonly generated by reactions enhanced by deformation and heat during regional metamorphism. The age of the mineralization in the region has been a matter of debate for decades: Ages ranging from the Archean to the Neoproterozoic are mentioned in the literature. In the mineralized zone from the Piteiras mine fluorine-aluminum-bearing titanite is found in metamafic rocks. The fluorine content was probably derived from the Borrachudos granites and pegmatites like the beryllium for emerald, thus both minerals could have been generated during the same event. U-Pb titanite geochronology via laser ablation inductively coupled plasma mass spectrometry (LA-ICP-MS) was performed on a thin section of a phlogopite-plagioclase-hornblende schist from the Piteiras mine. The determined age of $576 \pm 7 \mathrm{Ma}$ is also the probable age for emerald generation during the Brasiliano cycle, which was the only tectonometamorphic event postdating the intrusion of the granites. This event provided heat and fluids necessary for reactions between the Be- and the Cr-bearing rocks, thus enabling the formation of emeralds.
\end{abstract}

KEYWORDS: Titanite, U/Pb geochronology, Neoproterozoic, Emerald, Brazil.

\begin{abstract}
RESUMO: No Distrito Esmeraldifero de Itabira-Nova Era, sudeste do Brasil, esmeralda gemológica é extraída em minas subterrâneas em depósitos do Tipo Xisto na zona de contato da sequência metavulcanossedimentar arqueana do Complexo Guanhães com granitos anorogênicos paleoproterozoicos da Suite Borrachudos. Depósitos do Tipo Xisto são comumente gerados por reaçôes promovidas por deformação e calor durante metamorfismo regional. A idade da mineralização na regiāo tem sido motivo de debates por décadas: idades variando do Arqueano ao Neoproterozoico são mencionadas na literatura. Na zona mineralizada da mina Piteiras, titanita portadora de aluminio e fuior é encontrada em rochas metamáficas. O conteúdo de flúor foi provavelmente derivado dos granitos e pegmatitos Borrachudos, tal como o berílio para a esmeralda, portanto ambos minerais podem ter sido gerados durante o mesmo evento. Geocronologia U-Pb via ablação a laser associada a espectrometria de massa por plasma acoplado indutivamente laser (LA-ICP-MS) em titanita foi realizada em uma seção delgada de um flogopita-plagioclásio-hornblenda xisto da mina Piteiras. A idade determinada de $576 \pm 7$ Ma é também a provável idade de geração da esmeralda durante o ciclo Brasiliano, que foi o único evento tectonometamórfico posterior à intrusäo dos granitos. Este evento forneceu calor e fluidos necessários para reaçóes entre as rochas portadoras de berílio e de cromo, possibilitando assim a formação de esmeralda.
\end{abstract}

PALAVRAS CHAVE: Titanita, geocronologia U/Pb, Neoproterozoico, Esmeralda, Brazil.

${ }^{1}$ Departamento de Geologia, Escola de Minas, Universidade Federal de Ouro Preto (UFOP) - Ouro Preto (MG), Brazil. E-mails: hanna@degeo.ufop.br, cristianodeclana@gmail.com, delgado@geologist.com,deiwysviana@gmail.com

*Corresponding author.

Manuscript ID: 20160074. Received In: 06/13/2016. Approved In: 06/14/2016. 


\section{INTRODUCTION}

The formation of emeralds requires the uncommon interaction of beryllium and chromium, the latter being the usual chromophore element responsible for the typical green color. $\mathrm{Be}$ and $\mathrm{Cr}$ are incompatible elements found in quite distinct geochemical environments; while $\mathrm{Be}$ is concentrated in granitic rocks and their pegmatites, higher amounts of $\mathrm{Cr}$ are mostly found in mafic, and especially ultramafic igneous rocks. In order to enable the formation of emerald, reactions between these two contrasting lithotypes are usually enhanced by deformation. Among the emerald deposits found worldwide, the schist type is one of the most important. The reactions involved in the formation of this type of deposit usually happen during a tectonometamorphic event since the simple intrusion of granites or pegmatites in ultramafic rocks is not able to supply enough energy and fluids to produce important reaction zones (Franz et al. 1996, Franz \& Morteani 2002). As suggested by Grundmann and Morteani (1989), most if not all schist-type emerald deposits in metamorphic rocks may be the product of a deformational event accompanied or followed by regional metamorphism which provided heat and the abundant fluids necessary for the reactions of $\mathrm{Be}$ - and $\mathrm{Cr}$-rich rocks. In addition, the transformation of the original ultramafic rock (peridotites and/or their volcanic equivalents such as komatiites) into the typical emerald-bearing phlogopite schists is due to the percolation of K-rich fluids derived from pegmatites under the influence of deformation.

The Itabira-Nova Era Emerald District (Fig. 1), located ca. $120 \mathrm{~km}$ northeast of Belo Horizonte, state of Minas Gerais, Brazil, is known worldwide for the production of high-quality emerald gems. The two main mines, Belmont and Capoeirana, besides the temporarily closed mines Piteiras and Rocha, are found at the contact zone of metaultramafic phlogopite schists of the Metavolcanosedimentary Sequence correlative of the Archean Guanhães Complex (Padilha et al. 2000) and the Paleoproterozoic anorogenic Borrachudos granites (Dorr and Barbosa 1963, Grossi-Sad et al. 1990, Dossin et al. 1993, Chemale Jr. et al. 1997, Silva et al. 2002). Souza (1988), Giuliani et al. (1990), Souza et al. (1992), Machado (1998), Schwarz and Giuliani (2001), Schwarz

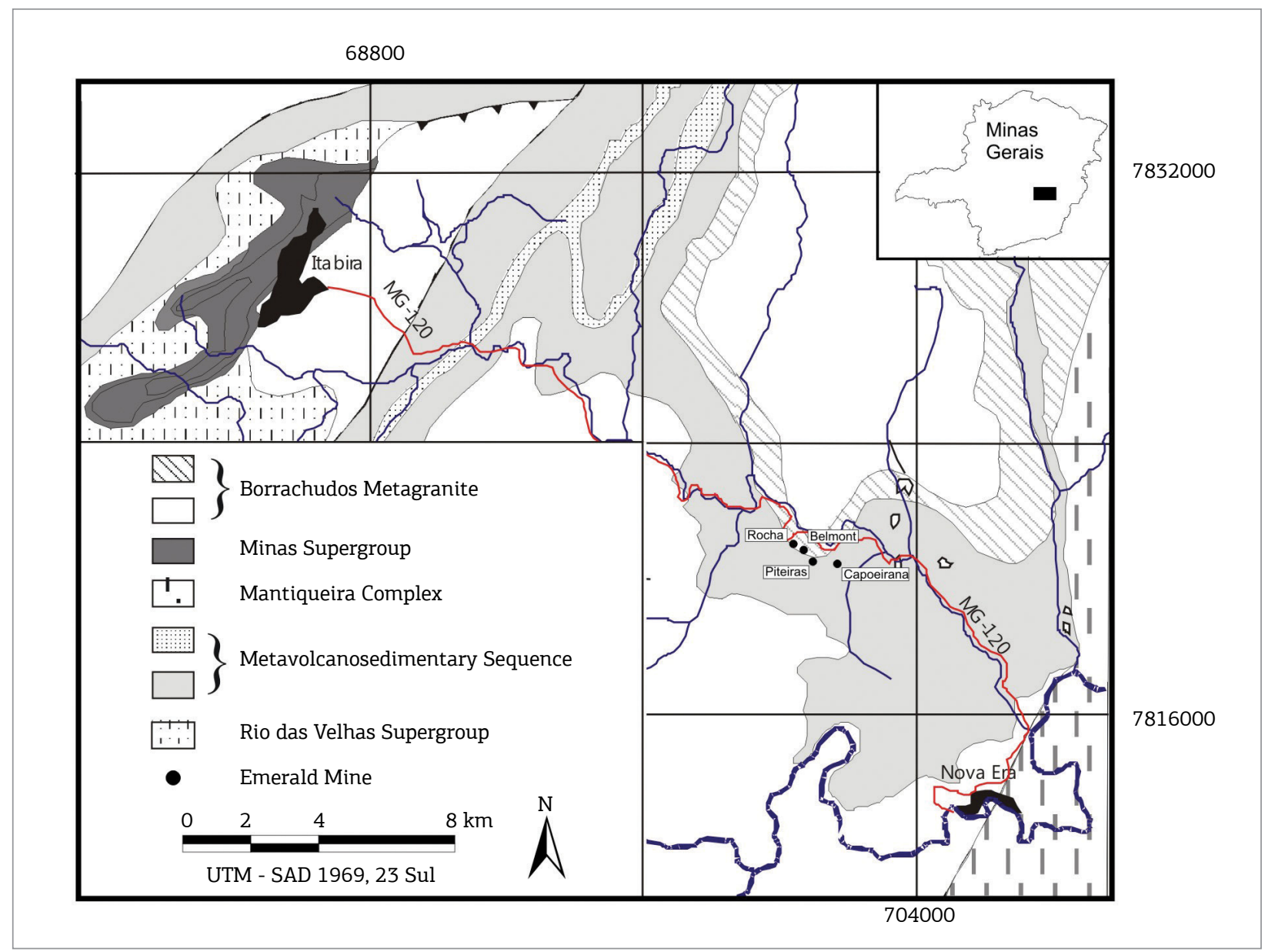

Figure 1. Simplified geological map of the area of the Itabira-Nova Era Emerald District (modified from Machado 1998) and the location of the emerald mines Piteiras, Belmont, Rocha, and Capoeirana. 
et al. (2002), and Franz and Morteani (2002) have classified the deposits of Belmont and Capoeirana as belonging to the schist type. Similar studies by Viana (2004), Viana et al. (2006), and Delgado (2007) in the mines Piteiras and Rocha led to the conclusion that also in these mines the emerald deposit is of identical origin.

The age of the schist-type mineralization in the ItabiraNova Era Emerald District remains debatable. More than one phase of mineralization was described by some authors based on the observation of two types of emeralds: one strongly deformed and therefore considered as older, and another undeformed and therefore postulated as being younger (Machado 1994, 1998, Ribeiro-Althoff et al. 1997, Morteani et al. 2000, Preinfalk et al. 2002, Ribeiro 2006). Schorscher (1991), Machado (1994, 1998), and Ribeiro (2006) interpreted the strongly deformed generation as of Archean age and the underformed generation as being Proterozoic. However, if the growth of emeralds lasts during the whole time span of a tectonometamorphic event, the early-formed crystals would be deformed while the late crystals remain undeformed. Considering that the mineralization is controlled by the spatial association of the Archean Metavolcanosedimentary Sequence with the Paleoproterozoic Borrachudos granite plutons and their pegmatites, the mineralization cannot be Archean. A Paleoproterozoic age for the mineralization was postulated by Preinfalk et al. (2002) based on Rb-Sr dating of pegmatites associated with the Borrachudos anorogenic metagranitoids. If, as discussed earlier, the generation of schist-type mineralization is associated with a tectonometamorphic event, the emerald formation in the region of Itabira-Nova Era cannot be of the same age as the $1.7 \mathrm{Ga}$ Borrachudos magmatism because at that time the Transamazonian $(-2.0 \mathrm{Ga})$ tectonometamorphic event had already ceased. The only major tectonometamorphic event in the region postdating the intrusion of the Borrachudos granites is the Brasiliano event $(-0.7-0.5 \mathrm{Ga})$ that could therefore be responsible for the emerald generation.

In order to check if the Brasiliano tectonometamorphic event played a role during the generation of the schist-type emerald mineralization, this paper presents the results of in situ laser ablation inductively coupled plasma mass spectrometry (LA-ICP-MS) U-Pb age determination on metamorphic fluorine-aluminum-bearing titanite belonging to a metamafic schist found in the mineralized zone from the Piteiras mine. The generation of both titanite and emerald was probably synchronous, therefore the age of the titanite is relevant to establish the age of the mineralization.

\section{Geological Setting}

The Itabira-Nova Era emerald deposits belong to the Santa Maria de Itabira Pegmatite District (Netto et al. 1998), in the southern portion of the Eastern Brazilian Pegmatite Province (Paiva 1946, Correia Neves et al. 1986). The deposits are located near the northeastern border of the Quadrilátero Ferrifero (QF), which is an important province for gold and iron deposits (Dorr 1969).

The oldest rocks of Archean age of this region record the influence of two younger orogenic events, the Transamazonian $(-2 \mathrm{Ga})$ and the Brasiliano $(0.7$ - 0.5 Ga; Brito Neves \& Cordani 1991, Alkmim and Marshak 1998). The strong influence of the Brasiliano event in the region of ItabiraNova Era is recorded in the regional structures described by Peres et al. (2004) and Padilha et al. (2000) as well as in geochronological data by Ribeiro-Althoff et al. (1997), Fernandes et al. (2000), and Preinfalk et al. (2002).

The geological outline in the Itabira-Nova Era region (Fig. 1) is defined by the envelopment of metagranitic plutons of the Paleoproterozoic Borrachudos Suite (Grossi-Sad et al. 1990) by rocks of the Metavolcanosedimentary Sequence correlative of the Archean Guanhães Complex (Padilha et al. 2000). The emerald mineralization is found mainly at this contact zone. Rocks belonging to the Archean Rio das Velhas greenstone belt, and to the Paleoproterozoic Minas Supergroup and Mantiqueira Complex are found locally. Additional lithotypes are younger metamafic bodies and the pegmatites associated with the emerald mineralization.

Although gneisses and metagranitoids are prevalent in the area, there is no consensus about their spatial arrangement and stratigraphic relationship; thereby the crystalline basement has been recorded in the literature as belonging to the Guanhães or to the Mantiqueira complexes. Souza (1988) and Schorscher (1991) named the rocks of the crystalline basement as Archean TTG Complex. The lithotypes of the Metavolcanosedimentary Sequence are metaultramafic, metamafic, and metasedimentary rocks that occur as meter-sized intercalations within TTG gneisses and migmatites dated at $2.9-2.7 \mathrm{Ga}(\mathrm{U} / \mathrm{Pb}$ SHRIMP age, Silva et al. 2002). In the area of the emerald mines, the metaultramafic rocks host the emerald mineralization.

The main lithotypes of the Mantiqueira Complex are banded and locally migmatized ortognaisses of granitic, granodioritic, and tonalitic composition. Lenses of amphibolites are relatively common. U-Pb SHRIMP age determinations resulted in Paleoproterozoic magmatic crystallization ages of $2.21-2.05 \mathrm{Ga}$ and metamorphic ages of $2.05 \mathrm{Ga}$ and of $560 \mathrm{Ma}$ (Silva et al. 2002).

Sericitic and ferruginous quartzite and phyllite, banded iron formations, and marble are the rock types of the Minas Supergroup in the Itabira-Nova Era region.

Metagranitic bodies of the Borrachudos Suite make up most of the area in Figure 1. They are composed of anorogenic alkaline metagranites related to the opening of the 
Espinhaço rift (Chemale Jr. 1987, Fernandes et al. 1995, Chemale Jr. et al. 1997, Dussin et al. 1997, Silva et al. 2002). Shear zones leading to variable degrees of gneissification are common (Peres et al. 2004). Quartz, microcline, plagioclase (commonly nearly pure albite, Jordt-Evangelista $e t a l$. 2000) and biotite are the main minerals. Additionally, there are subordinated amounts of hornblende, titanite, apatite, garnet, zircon, ilmenite, and fluorite. Fluorite is a diagnostic mineral for the Borrachudos granitoids, enabling its distinction from the quartz-feldspar-rich rocks belonging to other geological units. Single-zircon dating by stepwise $\mathrm{Pb}$ evaporation yielded a Paleoproterozoic crystallization age of $1.7 \mathrm{Ga}$ for the Borrachudos granite (Dossin et al. 1993) corroborated by the $1.74 \mathrm{Ga}$ U-Pb SHRIMP age by Silva et al. (2002). Neoproterozoic U/Pb ages of $620 \mathrm{Ma}$ on zircon were obtained by Fernandes et al. (2000) for the metamorphism and anatexis of the Borrachudos Suite.

Pegmatites occur as veins, dykes, and pods within all rock units of the region. They are mostly composed of albite, less common are quartz, micas, and microcline. Accessory minerals not found in all pegmatites are beryl, apatite, molybdenite, chrysoberyl, monazite, and titanite. Preinfalk et al. (2002) dated the pegmatites by the Rb-Sr method and found an older, 1.9 Ga generation, and a younger, dated $480 \mathrm{Ma}$ that is associated with the migmatization of the Borrachudos granite. ${ }^{40} \mathrm{Ar} /{ }^{39} \mathrm{Ar}$ age of $508 \pm 2 \mathrm{Ma}$ was determined by Ribeiro-Althoff et al. (1997) on biotite from the emerald-bearing biotitites at Capoeirana, which was considered as the emerald forming event. However, this Brasiliano age was considered by Preinfalk et al. (2002) as the rejuvenation rather than the crystallization age. The formation of a second emerald generation during the Brasiliano event is not excluded by Preinfalk et al. (2002).

\section{Piteiras Mine}

The country rocks in the Piteiras Mine where the dated titanite sample was collected are centimeter to decimeter thick banded gneisses belonging to the Metavolcanosedimentary Sequence correlative of the Guanhães Complex. They are made up of quartz, plagioclase, biotite, and garnet, less commonly also staurolite, kyanite, and fibrolitic sillimanite. These paragneisses show gradational contacts with biotite gneisses of tonalitic to granodioritic composition. Less commonly layers of quartz-plagioclase-anthophyllite granofels can be found. PT-conditions of the amphibolite facies are indicated by the presence of staurolite. These conditions were corroborated by geothermobarometric calculations which resulted in $T=610^{\circ} \mathrm{C}$ and $\mathrm{P}=5.2 \mathrm{kbar}$ (Viana et al. 2006). The emerald mineralization occurs in a $2-4 \mathrm{~m}$ thick and hundreds of meters long phlogopite-rich horizon. Due to folding, the thickness may locally reach
$12 \mathrm{~m}$. The mineralized metamafic/metaultramafic horizon comprises amphibole-biotite schists enclosing centimeter to meter thick lenses of gneisses similar to the above described country rocks, of amphibole schists (also named ultramafic amphibolites), of amphibolite, and of phlogopite schist. Pegmatites occur as irregular bodies up to $8 \mathrm{~m}$ long which may be concordant or discordant in relation to the metamorphic foliation and the compositional banding of the schists and gneisses. Most usually they are decimeter to meter sized, rounded to elongated, and fractured bodies involved by the foliation. The major mineral is albite, more seldom graphic quartz, microcline, beryl, and pockets of muscovite and clinochlore can be found. The association of phlogopitization with the pegmatites is indicated by the observation that phlogopite schists are nearly monomineralic near the pegmatites while farther away they are hornblende bearing (Fig. 2). The amount of phlogopite increases and that of amphibole decreases towards the pegmatites. The emerald-bearing phlogopite schist constitutes coarse grained, strongly foliated and easily disaggregated decimeter to meter thick layers and pods enclosing quartz \pm feldspar veins. Talc appears along fault surfaces oriented parallel to the metamorphic foliation. Quartz and fluorite are secondary minerals that were introduced into the phlogopitite during the metassomatic transformation. It is worthwhile to note that quartz is absent in samples that contain Mg-hornblende besides phlogopite, possibly because this rock type was less transformed during metasomatism than the phlogopitite, as is also indicated by relics of Al-rich chromite preserved from the original ultramafic rock.

Emerald occurs in the phlogopitite and in the quartz veins as porphyroblasts which are sometimes bent or fractured. Centimeter to decimeter thick veins composed of quartz, feldspar, or quartz plus feldspar are found in the phlogopite schist. The quartz veins appear farther away from the pegmatites and contain the best-colored emerald crystals. In the feldspathic veins the emerald crystals are less well formed, commonly showing corroded outlines.

\section{MATERIAL AND METHODS}

The studied rock sample (Sample PI-5) is a phlogopite-plagioclase-hornblende schist belonging to the subterraneous emerald mineralized zone in the Piteiras mine. The sample was chosen for geochronology due to two characteristics:

1. the presence of abundant metamorphic titanite surrounding ilmenite relics (Fig. 3), suggesting that titanite was formed during the same tectonometamorphic event responsible for the generation of the schist; and 


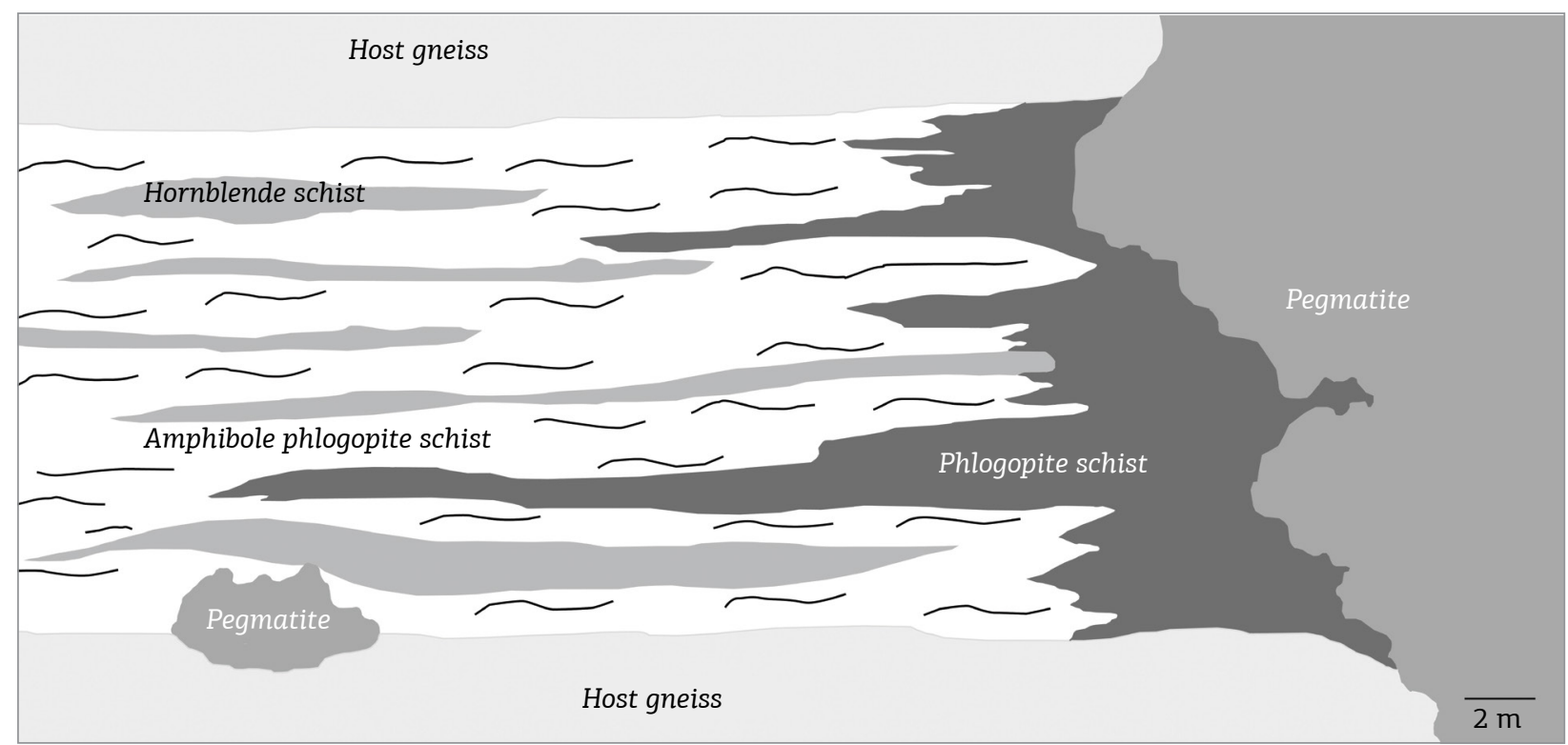

Figure 2. Schematic illustration showing the location of an emerald-bearing phlogopite schist adjacent to a pegmatite body in the Piteiras Mine (Viana 2004).
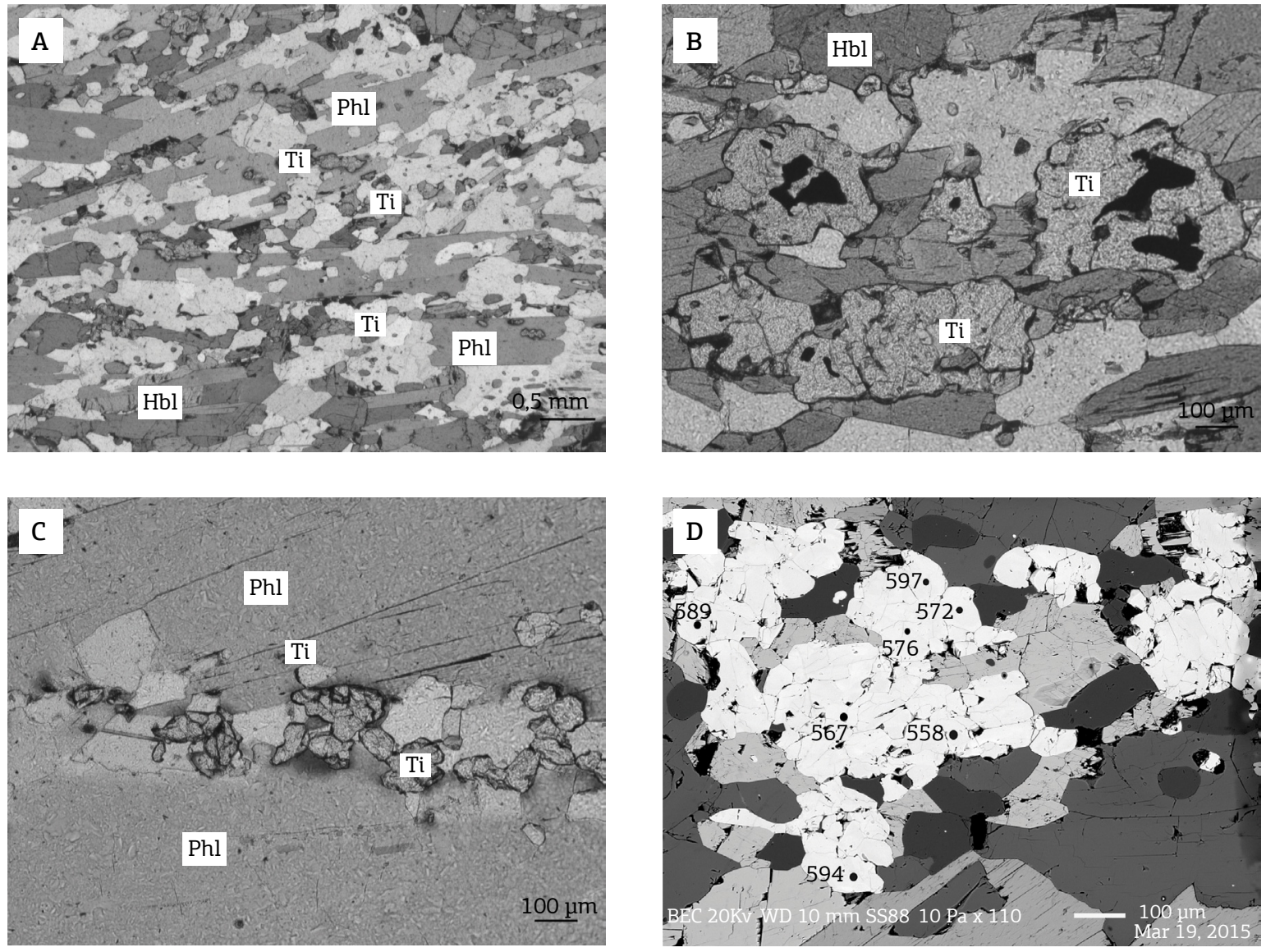

Figure 3. Photomicrographs $(\mathrm{A}-\mathrm{C})$ of thin section of the dated metamafic schist under plane polarized light. (A) General view showing titanite (grains with high relief), phlogopite, Mg-hornblende, plagioclase, and quartz (both colorless). (B) Ilmenite (black) surrounded by titanite. (C) Titanite grains surrounded by pleochroic haloes in phlogopite. (D) Ages (in million years) of titanite grains plotted on BSE-image. $\mathrm{Ti}=$ titanite; $\mathrm{Phl}=$ phlogopite; $\mathrm{Hbl}=\mathrm{Mg}$-hornblende. 
2. the unusual high fluorine content (Table 1) in the titanite that was probably derived from the Borrachudos granites that were also the source of the Be for the emerald generation.

Thin sections were described on a Leica DM EP microscope at the Departamento de Geologia (DEGEO), Universidade Federal de Ouro Preto. Microprobe analyses on the titanite were performed on a JEOL microprobe JXA $8900 \mathrm{RL}$, at the Laboratório de Microanálises of the Universidade Federal de Minas Gerais, Belo Horizonte, Brazil. Operating conditions were $20 \mathrm{kV}, 10 \mu \mathrm{m}$ beam, and counting time of $100 \mathrm{~s}$. The LA-ICP-MS analyses were performed using a Thermo Scientific Element II and a $213 \mathrm{~nm}$ CETAC laser at the isotope/geochemistry laboratory of the Department of Geology, Universidade Federal de Ouro Preto. The analyses were performed on a conventional polished ( $30 \mu \mathrm{m}$-thick) thin section. Sample contamination is excluded because the thin section was as clean as any other epoxy mount and $100 \%$ free of common $\mathrm{Pb}$. In addition, the analyzed titanite grains were mostly larger than $200 \mu \mathrm{m}$ whereas the laser holes were narrow $(20 \mu \mathrm{m}$-wide) and substantially shallow (less than $5 \mu \mathrm{m}$-deep). Acquisitions consisted of $20 \mathrm{~s}$ measurement of the gas blank, followed by $20 \mathrm{~s}$ measurement of $\mathrm{U}$, $\mathrm{Th}$, and $\mathrm{Pb}$ signals during ablation, and $20 \mathrm{~s}$ washout. Laser conditions were $20 \mu \mathrm{m}$ beam at $10 \mathrm{~Hz}$ and $0.02 \mathrm{~J}$ energy, giving a fluency of $8 \mathrm{~J} / \mathrm{mm}$. Common $\mathrm{Pb}$ corrected isotopic ratios were reduced using an Excel spreadsheet (Gerdes $\&$ Zeh 2006). Apparent age calculations and concordia diagrams were produced using Isoplot 4 (Ludwig 2012).
Two standards were used during runs: the primary standard BLR (1049.9 \pm 1.3 Ma; Aleinikoff et al. 2007) and the secondary standard Khan titanite $(522.2 \pm 2.2 \mathrm{Ma}$, Heaman 2009). Twenty-five within-run analyses of the secondary standard gave a concordia age of $524 \pm 2.6 \mathrm{Ma}$ whereas six analyses of BLR (as secondary standard) gave a concordia age of $1053 \pm 10 \mathrm{Ma}$ (Table 2 ).

\section{RESULTS}

\section{Petrography}

Sample PI-5 comes from an amphibolite facies metamafic schist (Fig. 3A) of the mineralized zone at the Piteiras mine. It is composed of $\mathrm{Mg}$-hornblende (40 vol.\%), phlogopite (25 vol.\%), plagioclase (23 vol.\%), quartz (7 vol.\%), and titanite (5 vol.\%). There is a mineralogical layering with hornblende-rich layers alternating with phlogopite-rich ones. Titanite (Fig. 3A-C) is more abundant in the phlogopite-rich layers, where it may reach about 10 vol.\%. Ilmenite is a relictic accessory mineral being always surrounded by titanite (Fig. 3B).

\section{Fluorine-aluminum-bearing titanite}

In metamafic rocks of the mineralized zone from the Piteiras mine, Al-rich titanite commonly constitutes 0.5 $1 \mathrm{~mm}$ large clusters that may surround ilmenite relics (Fig. 3B). Titanite is characterized by relatively low interference colors of upper second to lower third order and for

Table 1. Chemical composition (wt.\%) by microprobe analyses of fluorine-aluminum-bearing titanite from the Piteiras mine.

\begin{tabular}{l|c|c|c|c|c|c|c|c}
\hline & $\mathbf{S i O}_{2}$ & $\mathrm{TiO}_{2}$ & $\mathbf{A l}_{2} \mathbf{O}_{3}$ & $\mathbf{F e O}$ & $\mathbf{M n O}$ & $\mathbf{C a O}$ & $\mathbf{F}$ & Sum \\
\hline PI5-Ca-Tit-1 & 31.48 & 28.76 & 8.01 & 0.75 & 0.08 & 28.60 & 2.39 & 100.07 \\
\hline PI5-Ca-Tit-2 & 31.42 & 27.59 & 8.96 & 0.55 & 0.13 & 29.13 & 2.86 & 100.64 \\
\hline PI5-Ca-Tit-3 & 31.32 & 31.14 & 6.45 & 0.69 & 0.11 & 29.02 & 2.38 & 101.11 \\
\hline PI5-Ca-Tit-4 & 31.18 & 28.28 & 8.35 & 0.67 & 0.11 & 29.06 & 2.84 & 100.49 \\
\hline PI5-Ca-Tit-5 & 31.21 & 29.64 & 7.45 & 0.82 & 0.15 & 28.80 & 2.21 & 100.28 \\
\hline PI5-Ca-Tit-6 & 30.86 & 29.27 & 7.47 & 0.72 & 0.15 & 28.53 & 2.64 & 99.64 \\
\hline PI5-Ca-Tit-7 & 30.68 & 27.87 & 8.38 & 0.56 & 0.11 & 28.69 & 2.09 & 98.38 \\
\hline PI5Ca-C1-Tit-8 & 30.34 & 27.80 & 8.34 & 0.63 & 0.05 & 28.30 & 1.84 & 97.30 \\
\hline PI5Ca-C1-Tit-9 & 30.67 & 28.93 & 7.47 & 0.71 & 0.15 & 28.11 & 2.16 & 98.20 \\
\hline PI5Ca-C1-Tit-10 & 31.15 & 28.16 & 7.89 & 0.68 & 0.09 & 28.35 & 2.49 & 98.81 \\
\hline PI5Ca-C1-Tit-11 & 30.87 & 29.10 & 7.26 & 0.70 & 0.10 & 28.37 & 2.66 & 99.06 \\
\hline PI5Ca-C1-Tit-12 & 30.56 & 29.95 & 7.19 & 0.66 & 0.06 & 28.54 & 1.67 & 98.63 \\
\hline
\end{tabular}


Hanna Jordt-Evangelista et al.

Table 2. Results of U-Pb LA-ICP-MS dating of titanite from the Piteiras mine in the Itabira-Nova Era Emerald District.

\begin{tabular}{|c|c|c|c|c|c|c|c|c|c|c|c|c|c|c|c|c|c|c|c|}
\hline Spot & $\begin{array}{c}{ }^{2} 207 \\
\mathrm{~Pb} \\
\text { (cps) }\end{array}$ & $\begin{array}{c}\text { bU } \\
\text { (ppm) }\end{array}$ & $\begin{array}{c}{ }^{\mathrm{b}} \mathrm{Pb} \\
\text { (ppm) }\end{array}$ & $\frac{{ }^{\mathrm{b}} \mathrm{Th}}{\mathrm{U}}$ & $\begin{array}{c}{ }^{2} 206 \\
\mathrm{~Pb} \\
(\%)\end{array}$ & $\begin{array}{c}\mathrm{d}^{\mathrm{2}} 207 \\
\mathrm{~Pb} \\
235 \mathrm{U}\end{array}$ & $\begin{array}{l} \pm 2 s \\
(\%)\end{array}$ & $\begin{array}{c}\mathrm{d} 206 \\
\mathrm{~Pb} \\
238 \mathrm{U}\end{array}$ & $\begin{array}{l}+2 \mathrm{~s} \\
(\%)\end{array}$ & rhoe & $\begin{array}{c}\mathrm{d}^{207} \\
\mathrm{~Pb} \\
206 \\
\mathrm{~Pb}\end{array}$ & $\begin{array}{l}+2 s \\
(\%)\end{array}$ & $\begin{array}{c}206 \\
\mathrm{~Pb} \\
238 \\
\mathrm{U}\end{array}$ & $\begin{array}{c}+2 \mathrm{~s} \\
(\mathrm{Ma})\end{array}$ & $\begin{array}{c}207 \\
\mathrm{~Pb} \\
235 \\
\mathrm{U}\end{array}$ & $\begin{array}{l} \pm 2 \mathrm{~s} \\
(\mathrm{Ma})\end{array}$ & $\begin{array}{c}207 \\
\mathrm{~Pb} \\
206 \\
\mathrm{~Pb}\end{array}$ & $\begin{array}{c} \pm 2 \mathrm{~s} \\
(\mathrm{Ma})\end{array}$ & $\begin{array}{c}\text { Conc } \\
\%\end{array}$ \\
\hline
\end{tabular}

\section{Sample PI-5}

\begin{tabular}{|c|c|c|c|c|c|c|c|c|c|c|c|c|c|c|c|c|c|c|c|}
\hline 4.sSMPABC056 & 4910 & 19.00 & 1.96 & 0.06 & 0.255 & 0.731 & 2.770 & 0.091 & 2.279 & 0.823 & 0.059 & 1.574 & 559 & 12 & 557 & 12 & 550 & 34 & 101.65 \\
\hline 4.SSMPABC055 & 4893 & 19.62 & 2.06 & 0.06 & 0.074 & 0.746 & 3.036 & 0.092 & 2.520 & 0.830 & 0.059 & 1.693 & 568 & 14 & 566 & 13 & 558 & 37 & 101.85 \\
\hline 4.sSMPABCO30 & 466 & 2.50 & 0.26 & 0.01 & 0.954 & 0.844 & 6.658 & 0.104 & 4.507 & 0.677 & 0.059 & 4.901 & 637 & 27 & 621 & 31 & 566 & 107 & 112.59 \\
\hline 4.sSMPABC016 & 486 & 3.41 & 0.31 & 0.01 & 1.128 & 0.730 & 6.987 & 0.090 & 4.776 & 0.684 & 0.059 & 5.099 & 554 & 25 & 556 & 30 & 568 & 111 & 97.56 \\
\hline 4.sSMPABC078 & 883 & 2.20 & 0.20 & 0.01 & 2.045 & 0.740 & 5.216 & 0.090 & 3.363 & 0.645 & 0.060 & 3.988 & 556 & 18 & 562 & 23 & 587 & 87 & 94.84 \\
\hline 4.sSMPABCO26 & 500 & 2.26 & 0.21 & 0.01 & 1.553 & 0.749 & 6.495 & 0.091 & 4.019 & 0.619 & 0.060 & 5.102 & 562 & 22 & 568 & 29 & 591 & 111 & 95.19 \\
\hline 4.sSMPABC013 & 496 & 4.29 & 0.41 & 0.01 & 0.118 & 0.801 & 6.101 & 0.097 & 3.760 & 0.616 & 0.060 & 4.805 & 598 & 22 & 597 & 28 & 595 & 104 & 100.42 \\
\hline 4.sSMPABC082 & 849 & 1.84 & 0.17 & 0.01 & 0.572 & 0.754 & 4.551 & 0.091 & 3.209 & 0.705 & 0.060 & 3.226 & 563 & 17 & 570 & 20 & 598 & 70 & 94.15 \\
\hline 4.sSMPABCO34 & 707 & 2.82 & 0.26 & 0.01 & 0.797 & 0.783 & 4.908 & 0.095 & 3.205 & 0.653 & 0.060 & 3.717 & 583 & 18 & 587 & 22 & 605 & 80 & 96.35 \\
\hline 4.sSMPABCO32 & 463 & 1.96 & 0.19 & 0.01 & 1.986 & 0.794 & 6.064 & 0.096 & 3.506 & 0.578 & 0.060 & 4.948 & 590 & 20 & 593 & 28 & 605 & 107 & 97.55 \\
\hline 4.sSMPABCO11 & 723 & 5.88 & 0.56 & 0.01 & 1.524 & 0.778 & 5.175 & 0.094 & 3.600 & 0.696 & 0.060 & 3.718 & 579 & 20 & 584 & 23 & 606 & 80 & 95.48 \\
\hline 4.sSMPABC070 & 1198 & 2.92 & 0.26 & 0.01 & 2.526 & 0.745 & 4.427 & 0.090 & 2.660 & 0.601 & 0.060 & 3.539 & 555 & 14 & 565 & 19 & 607 & 77 & 91.52 \\
\hline 4.sSMPABC081 & 675 & 1.30 & 0.12 & 0.01 & 1.940 & 0.753 & 6.115 & 0.091 & 3.547 & 0.580 & 0.060 & 4.981 & 560 & 19 & 570 & 27 & 608 & 108 & 92.20 \\
\hline 4.sSMPABC084 & 27029 & 35.25 & 3.77 & 0.03 & 1.995 & 0.751 & 3.559 & 0.091 & 2.849 & 0.801 & 0.060 & 2.133 & 559 & 15 & 569 & 16 & 608 & 46 & 92.01 \\
\hline 4.sSMPABCO17 & 687 & 3.89 & 0.36 & 0.01 & 2.403 & 0.767 & 5.206 & 0.092 & 3.012 & 0.579 & 0.060 & 4.246 & 570 & 16 & 578 & 23 & 611 & 92 & 93.35 \\
\hline 4.SSMPABC079 & 617 & 1.12 & 0.10 & 0.01 & 2.846 & 0.746 & 6.715 & 0.090 & 4.664 & 0.695 & 0.060 & 4.831 & 555 & 25 & 566 & 30 & 611 & 104 & 90.71 \\
\hline 4.SSMPABCO53 & 27553 & 63.13 & 6.82 & 0.03 & 2.105 & 0.772 & 3.328 & 0.093 & 2.469 & 0.742 & 0.060 & 2.231 & 572 & 14 & 581 & 15 & 615 & 48 & 93.10 \\
\hline 4.sSMPABC075 & 1037 & 2.63 & 0.25 & 0.01 & 1.591 & 0.787 & 4.639 & 0.095 & 2.680 & 0.578 & 0.060 & 3.786 & 583 & 15 & 590 & 21 & 615 & 82 & 94.81 \\
\hline 4.sSMPABCO33 & 653 & 2.08 & 0.20 & 0.01 & 3.521 & 0.760 & 6.130 & 0.091 & 3.272 & 0.534 & 0.060 & 5.184 & 563 & 18 & 574 & 27 & 615 & 112 & 91.60 \\
\hline 4.sSMPABC052 & 27073 & 61.98 & 6.78 & 0.03 & 2.123 & 0.779 & 3.568 & 0.094 & 2.757 & 0.773 & 0.060 & 2.266 & 577 & 15 & 585 & 16 & 616 & 49 & 93.67 \\
\hline 4.sSMPABC083 & 801 & 1.41 & 0.13 & 0.01 & 2.043 & 0.751 & 5.885 & 0.090 & 3.782 & 0.643 & 0.060 & 4.509 & 557 & 20 & 569 & 26 & 618 & 97 & 90.16 \\
\hline 4.sSMPABCO22 & 760 & 3.77 & 0.36 & 0.01 & 1.282 & 0.780 & 4.898 & 0.094 & 3.430 & 0.700 & 0.060 & 3.496 & 577 & 19 & 586 & 22 & 620 & 75 & 93.05 \\
\hline 4.sSMPABCO31 & 703 & 2.59 & 0.24 & 0.01 & 2.487 & 0.786 & 5.089 & 0.094 & 2.895 & 0.569 & 0.060 & 4.186 & 581 & 16 & 589 & 23 & 607 & 90 & 95.71 \\
\hline 4.SSMPABC080 & 684 & 1.29 & 0.12 & 0.01 & 0.707 & 0.775 & 5.325 & 0.093 & 4.081 & 0.566 & 0.058 & 3.421 & 572 & 22 & 583 & 24 & 532 & 74 & 107.46 \\
\hline 4.sSMPABC054 & 28288 & 63.08 & 6.96 & 0.03 & 2.034 & 0.802 & 3.624 & 0.096 & 2.912 & 0.803 & 0.060 & 2.158 & 589 & 16 & 598 & 17 & 594 & 46 & 99.20 \\
\hline 4.sSMPABC050 & 27572 & 64.55 & 7.33 & 0.03 & 2.180 & 0.809 & 3.541 & 0.096 & 2.684 & 0.758 & 0.059 & 2.310 & 594 & 15 & 602 & 16 & 556 & 50 & 106.73 \\
\hline 4.sSMPABCO96 & 710 & 0.89 & 0.08 & 0.01 & 3.097 & 0.765 & 5.942 & 0.091 & 3.491 & 0.588 & 0.061 & 4.808 & 562 & 19 & 577 & 26 & 633 & 104 & 88.84 \\
\hline 4.sSMPABCO51 & 27430 & 62.79 & 7.13 & 0.03 & 1.972 & 0.814 & 3.412 & 0.097 & 2.679 & 0.585 & 0.060 & 2.112 & 596 & 15 & 605 & 16 & 607 & 45 & 98.25 \\
\hline 4.sSMPABCO14 & 632 & 3.87 & 0.37 & 0.01 & 2.482 & 0.800 & 6.095 & 0.095 & 4.238 & 0.695 & 0.061 & 4.381 & 586 & 24 & 597 & 28 & 638 & 94 & 91.85 \\
\hline 4.sSMPABCO25 & 632 & 2.58 & 0.25 & 0.01 & 2.469 & 0.802 & 6.090 & 0.095 & 4.238 & 0.696 & 0.060 & 4.374 & 586 & 24 & 598 & 28 & 607 & 94 & 96.49 \\
\hline 4.SSMPABCO95 & 608 & 0.66 & 0.06 & 0.01 & 3.756 & 0.762 & 6.166 & 0.090 & 3.783 & 0.583 & 0.059 & 4.869 & 557 & 20 & 575 & 27 & 578 & 105 & 96.26 \\
\hline 4.sSMPABCO15 & 510 & 2.49 & 0.26 & 0.01 & 3.866 & 0.804 & 6.671 & 0.095 & 4.615 & 0.592 & 0.060 & 4.818 & 584 & 26 & 599 & 31 & 588 & 103 & 99.31 \\
\hline 4.sSMPABCO29 & 510 & 1.61 & 0.17 & 0.01 & 3.853 & 0.806 & 6.666 & 0.095 & 4.615 & 0.692 & 0.059 & 4.810 & 584 & 26 & 600 & 31 & 556 & 103 & 104.92 \\
\hline 4.SSMPABCO73 & 583 & 0.95 & 0.10 & 0.01 & 4.340 & 0.788 & 5.845 & 0.092 & 4.257 & 0.728 & 0.058 & 4.005 & 567 & 23 & 590 & 26 & 534 & 86 & 106.24 \\
\hline 4.sSMPABCO12 & 529 & 2.77 & 0.29 & 0.01 & 4.408 & 0.834 & 6.198 & 0.097 & 4.484 & 0.723 & 0.059 & 4.279 & 595 & 26 & 616 & 29 & 550 & 91 & 108.35 \\
\hline 4.sSMPABCO97 & 32324 & 36.12 & 4.34 & 0.03 & 2.601 & 0.897 & 3.431 & 0.104 & 2.382 & 0.694 & 0.060 & 2.470 & 636 & 14 & 650 & 17 & 593 & 53 & 107.26 \\
\hline
\end{tabular}


Table 2. Continuation.

\begin{tabular}{|c|c|c|c|c|c|c|c|c|c|c|c|c|c|c|c|c|c|c|c|}
\hline Spot & $\begin{array}{c}{ }^{\mathrm{a}} 207 \\
\mathrm{~Pb} \\
\text { (cps) }\end{array}$ & $\begin{array}{c}\text { bU } \\
\text { (ppm) }\end{array}$ & $\begin{array}{c}\text { bPb } \\
\text { (ppm) }\end{array}$ & $\frac{{ }^{\mathrm{b}} \mathrm{Th}}{\mathrm{U}}$ & $\begin{array}{l}{ }^{2} 206 \\
\mathrm{~Pb} \\
(\%)\end{array}$ & $\begin{array}{c}{ }^{\mathrm{d}} 207 \\
\mathrm{~Pb} \\
235 \mathrm{U}\end{array}$ & $\begin{array}{l}+2 s \\
(\%)\end{array}$ & $\begin{array}{c}{ }^{\mathrm{d}} \mathbf{2 0 6} \\
\mathrm{Pb}\end{array}$ & $\begin{array}{l} \pm 2 s \\
(\%)\end{array}$ & rhoe & $\begin{array}{c}\mathrm{d}^{207} \\
\mathrm{~Pb} \\
206 \\
\mathrm{~Pb}\end{array}$ & $\begin{array}{l}+2 \mathrm{~s} \\
(\%)\end{array}$ & $\begin{array}{c}206 \\
\mathrm{~Pb} \\
238 \\
\mathrm{U}\end{array}$ & $\begin{array}{c}+2 \mathrm{~s} \\
(\mathrm{Ma})\end{array}$ & $\begin{array}{c}207 \\
\mathrm{~Pb} \\
235 \\
\mathrm{U}\end{array}$ & $\begin{array}{c}+2 \mathrm{~s} \\
(\mathrm{Ma})\end{array}$ & $\begin{array}{c}207 \\
\mathrm{~Pb} \\
206 \\
\mathrm{~Pb}\end{array}$ & 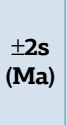 & $\begin{array}{c}\text { Conc } \\
\%\end{array}$ \\
\hline
\end{tabular}

Khan Accepted age $522 \mathrm{Ma}$

Within run standard points normalized with BLR 1

\begin{tabular}{|c|c|c|c|c|c|c|c|c|c|c|c|c|c|c|c|c|c|c|c|}
\hline 4.sSMPABC094 & 4852 & 10.38 & 1.00 & 0.06 & 0.000 & 0.668 & 2.986 & 0.084 & 2.512 & 0.841 & 0.058 & 1.614 & 521 & 13 & 520 & 12 & 516 & 35 & 100.90 \\
\hline 4.sSMPABCO93 & 4891 & 9.93 & 0.96 & 0.06 & 0.410 & 0.674 & 2.784 & 0.084 & 2.318 & 0.833 & 0.058 & 1.542 & 522 & 12 & 523 & 11 & 529 & 34 & 98.60 \\
\hline 4.sSMPABC092 & 4827 & 10.47 & 1.03 & 0.06 & 0.000 & 0.689 & 2.649 & 0.086 & 2.252 & 0.850 & 0.058 & 1.395 & 532 & 12 & 532 & 11 & 535 & 31 & 99.32 \\
\hline 4.sSMPABC091 & 4933 & 10.56 & 1.03 & 0.06 & 0.352 & 0.684 & 2.985 & 0.085 & 2.487 & 0.833 & 0.058 & 1.652 & 527 & 13 & 529 & 12 & 539 & 36 & 97.70 \\
\hline 4.SSMPABCO90 & 4950 & 10.74 & 1.04 & 0.06 & 0.000 & 0.668 & 2.499 & 0.084 & 2.047 & 0.819 & 0.058 & 1.435 & 518 & 10 & 519 & 10 & 523 & 31 & 99.13 \\
\hline 4.sSMPABC089 & 25842 & 28.78 & 2.88 & 0.03 & 2.114 & 0.688 & 3.652 & 0.084 & 2.862 & 0.784 & 0.059 & 2.269 & 519 & 14 & 531 & 15 & 585 & 49 & 88.74 \\
\hline 4.sSMPABC086 & 30209 & 35.11 & 3.61 & 0.03 & 2.875 & 0.700 & 3.862 & 0.085 & 2.684 & 0.695 & 0.060 & 2.777 & 526 & 14 & 539 & 16 & 594 & 60 & 88.57 \\
\hline 4.sSMPABC084 & 799 & 1.21 & 0.11 & 0.01 & 3.453 & 0.678 & 5.969 & 0.082 & 3.855 & 0.646 & 0.060 & 4.557 & 510 & 19 & 525 & 25 & 593 & 99 & 86.06 \\
\hline 4.sSMPABC067 & 989 & 1.60 & 0.14 & 0.01 & 4.463 & 0.705 & 6.089 & 0.084 & 3.603 & 0.592 & 0.061 & 4.909 & 522 & 18 & 542 & 26 & 629 & 106 & 82.98 \\
\hline 4.sSMPABC066 & 934 & 2.02 & 0.18 & 0.01 & 1.712 & 0.684 & 5.093 & 0.084 & 2.945 & 0.578 & 0.059 & 4.154 & 517 & 15 & 529 & 21 & 582 & 90 & 88.85 \\
\hline 4.sSMPABC062 & 738 & 1.78 & 0.16 & 0.01 & 2.813 & 0.691 & 6.186 & 0.085 & 4.156 & 0.672 & 0.059 & 4.582 & 525 & 21 & 533 & 26 & 570 & 100 & 92.00 \\
\hline 4.sSMPABC068 & 5148 & 16.60 & 1.54 & 0.06 & 0.000 & 0.660 & 2.486 & 0.081 & 2.089 & 0.840 & 0.059 & 1.348 & 505 & 10 & 515 & 10 & 560 & 29 & 90.14 \\
\hline 4.sSMPABC067 & 5439 & 20.51 & 2.03 & 0.06 & 0.000 & 0.690 & 2.726 & 0.086 & 2.353 & 0.863 & 0.058 & 1.376 & 534 & 12 & 533 & 11 & 527 & 30 & 101.27 \\
\hline 4.sSMPABCO21 & 6311 & 43.67 & 4.33 & 0.06 & 0.000 & 0.685 & 3.212 & 0.086 & 2.865 & 0.892 & 0.058 & 1.452 & 531 & 15 & 530 & 13 & 525 & 32 & 101.21 \\
\hline 4.sSMPABCO20 & 6258 & 45.30 & 4.48 & 0.06 & 0.764 & 0.680 & 3.091 & 0.085 & 2.486 & 0.804 & 0.058 & 1.837 & 529 & 13 & 527 & 13 & 518 & 40 & 102.04 \\
\hline 4.sSMPABCO19 & 6036 & 45.36 & 4.53 & 0.06 & 0.000 & 0.680 & 3.094 & 0.086 & 2.745 & 0.887 & 0.058 & 1.428 & 529 & 14 & 527 & 13 & 518 & 31 & 102.10 \\
\hline 4.sSMPABCO18 & 6737 & 52.01 & 5.12 & 0.06 & 0.000 & 0.681 & 3.430 & 0.085 & 3.190 & 0.930 & 0.058 & 1.260 & 528 & 16 & 527 & 14 & 524 & 28 & 100.72 \\
\hline 4.sSMPABCO10 & 6244 & 73.33 & 7.35 & 0.06 & 0.000 & 0.696 & 3.228 & 0.087 & 2.872 & 0.890 & 0.058 & 1.473 & 537 & 15 & 536 & 14 & 531 & 32 & 101.25 \\
\hline 4.SSMPABCOO9 & 6258 & 78.25 & 7.74 & 0.06 & 0.764 & 0.680 & 3.091 & 0.085 & 2.486 & 0.804 & 0.058 & 1.837 & 529 & 13 & 527 & 13 & 518 & 40 & 102.04 \\
\hline 4.sSMPABCOO8 & 6092 & 80.12 & 7.94 & 0.06 & 0.000 & 0.673 & 3.075 & 0.085 & 2.728 & 0.887 & 0.058 & 1.421 & 524 & 14 & 522 & 13 & 514 & 31 & 101.99 \\
\hline 4.sSMPABCOO7 & 6737 & 92.46 & 9.11 & 0.06 & 0.000 & 0.681 & 3.430 & 0.085 & 3.190 & 0.930 & 0.058 & 1.260 & 528 & 16 & 527 & 14 & 524 & 28 & 100.69 \\
\hline 4.sSMPABCOO6 & 6406 & 94.36 & 9.38 & 0.06 & 0.000 & 0.687 & 3.437 & 0.086 & 3.143 & 0.914 & 0.058 & 1.391 & 532 & 16 & 531 & 14 & 524 & 31 & 101.52 \\
\hline 4.SSMPABCOO4 & 6418 & 107.70 & 10.67 & 0.06 & 0.000 & 0.676 & 3.037 & 0.085 & 2.772 & 0.913 & 0.058 & 1.241 & 526 & 14 & 524 & 13 & 517 & 27 & 101.83 \\
\hline 4.sSMPABCOO3 & 6216 & 114.69 & 11.20 & 0.06 & 0.000 & 0.665 & 3.270 & 0.084 & 2.989 & 0.914 & 0.057 & 1.325 & 519 & 15 & 518 & 13 & 510 & 29 & 101.93 \\
\hline
\end{tabular}

\section{BLR 1 Accepted age $1049 \mathrm{Ma}$}

Within run standard points normalized with BLR 1

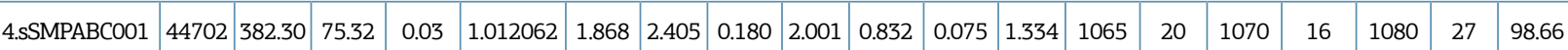

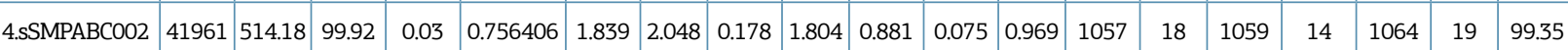

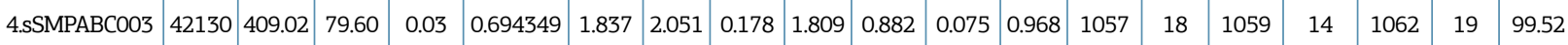

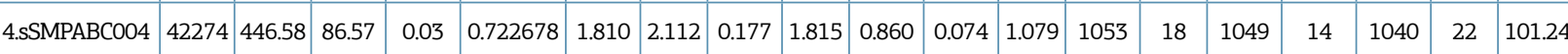

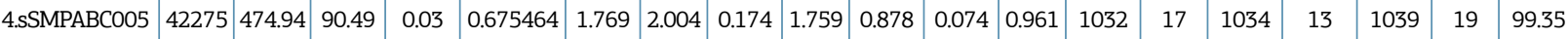

${ }^{a}$ Within run background-corrected mean ${ }^{207} \mathrm{~Pb}$ signal in cps (counts per second); ${ }^{\mathrm{U}} \mathrm{U}$ and $\mathrm{Pb}$ content and Th/U ratio were calculated relative to BLR reference STD; cpercentage of the common $\mathrm{Pb}$ on the ${ }^{206} \mathrm{~Pb}$. b.d. = below dectection limit; corrected for background. within-run $\mathrm{Pb} / \mathrm{U}$ fractionation (in case of $206 \mathrm{~Pb} / 238 \mathrm{U}$ ) and common Pb using Stacy and Kramers (1975) model Pb composition and subsequently normalised to GJ-1 (ID-TIMS value/ measured value); ${ }^{207} \mathrm{~Pb} / 235 \mathrm{U}$ calculated using ${ }^{207} \mathrm{~Pb} /{ }^{206} \mathrm{~Pb} /\left({ }^{238} \mathrm{U} /{ }^{206} \mathrm{~Pb}{ }^{*} 1 / 137.88\right)$; ${ }^{\text {erho }}$ is the ${ }^{206} \mathrm{~Pb} /{ }^{238} \mathrm{U} /{ }^{207} \mathrm{~Pb} / 235 \mathrm{U}$ error correlation coefficient. 
being surrounded by strong pleochroic haloes when included in phlogopite (Fig. 3C). Chemical analyses by electron microprobe show relatively high contents of $\mathrm{Al} 2 \mathrm{O} 3$ (7.198.96 wt.\%, Table 1) and fluorine (around 2 wt.\%). Due to the high $\mathrm{Al}$ content, this titanite was classified as grothite (Gaines et al. 1997) by Delgado et al. (2005).

\section{Geochronology}

Figure $3 \mathrm{D}$ is a BSE image of the sample PI-5, showing bright white titanite clusters with the location of some dated points. The mineral with light gray color is $\mathrm{Mg}$-hornblende and the dark gray ones are plagioclase and quartz. The sample consists of Mg-hornblende, phlogopite, plagioclase, quartz, and titanite and is marked by a strong foliation defined by hornblende and phlogopite. Note that titanite is part of this fabric indicating growth during the metamorphic event.

Thirty-six analyses were performed on center and rims of the titanite grains (Table 2). No age difference could be detected between center and rim of titanite grains. Pooling of all data points did not yield a concordia age (Fig. 4). The points scatter about a mean ${ }^{206} \mathrm{~Pb} /{ }^{238} \mathrm{U}$ age of $576 \pm 7 \mathrm{Ma}$ which is considered the age of titanite growth during medium-grade metamorphism.

\section{DISCUSSION AND CONCLUSIONS}

The substitution of Ti by $\mathrm{Al}$ in titanite, as found in the dated fluorine-aluminum-bearing titanite, can be the result of the high activity of fluorine that causes the simultaneous substitution of O by (F, OH) (Černý \& Povondra 1972). Thereafter, the discussions regarding the formation of the titanite must take into consideration the source of fluorine, which is a scarce element in mafic igneous rocks but relatively abundant in granitic rocks. The metamafic schist belongs to the Archean Metavolcanosedimentary Sequence that surrounds the $1.7 \mathrm{Ga}$ anorogenic Borrachudos metagranites. The Borrachudos metagranites postdate the main deformation phases of the 2.2-2.0 Paleoproterozoic Transamazonian tectonothermal event. The origin of fluorine must be linked to these granitic intrusions and their pegmatites which were also the source of beryllium for the emerald found in the associated phlogopite schists. The generation of emerald as well

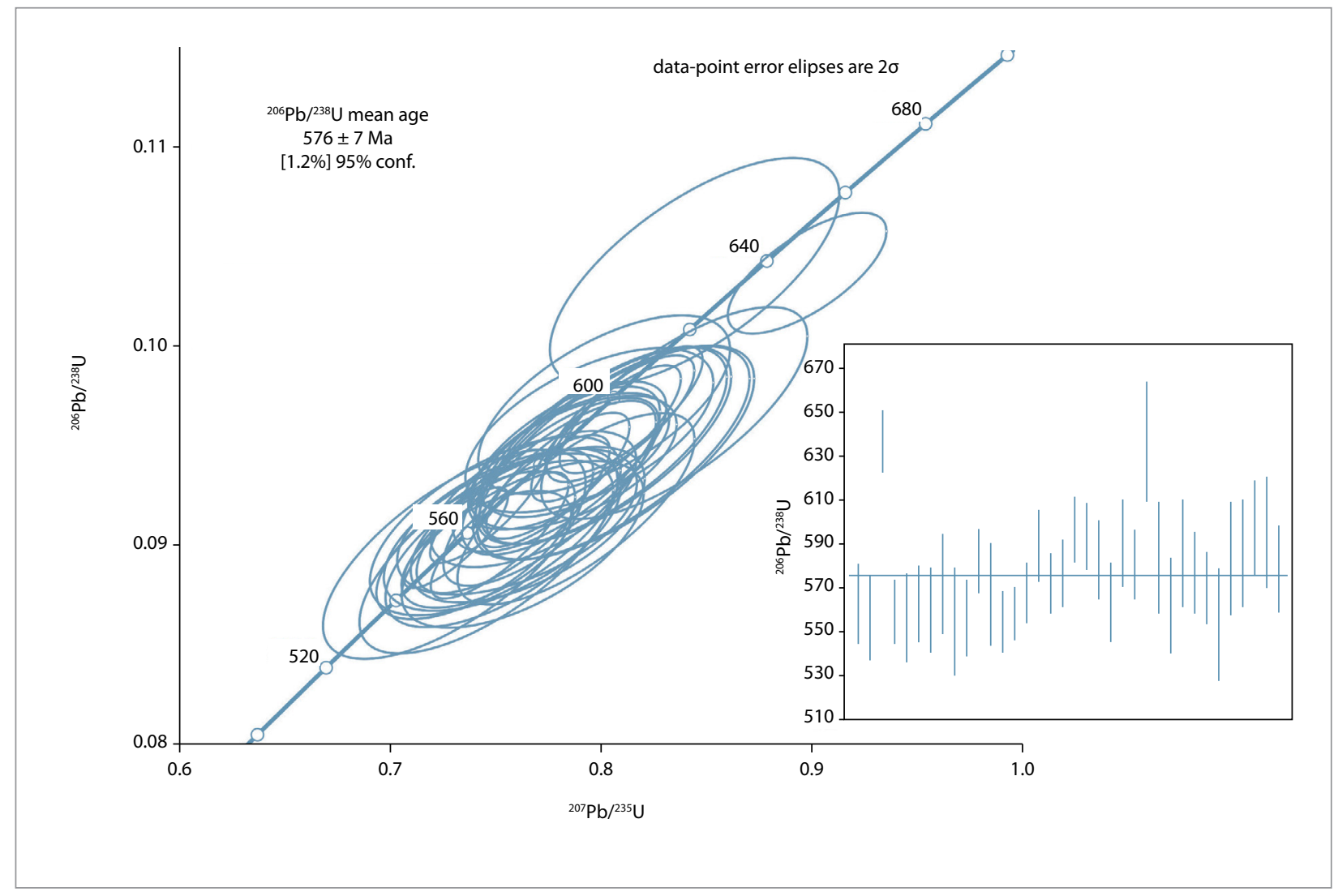

Figure 4. U-Pb concordia and weighed mean diagrams of LA-ICP-MS analyses of fluorine-aluminum-bearing titanite from a metamafic schist of the Piteiras mine. 
as the titanite was possibly due to the metassomatic introduction of, respectively, Be and $\mathrm{F}$ into the metaultramafic and metamafic rocks. The discussions on the age of titanite and emerald must also take into consideration the nature of the rocks where the two minerals are found: These rocks are strongly deformed and completely metamorphosed and transformed by metassomatic reactions. As discussed in the literature (Grundmann \& Morteani 1989, Franz et al. 1996, Franz \& Morteani 2002), the formation of schist-type emerald deposits such as that of the Piteiras mine involves a tectonometamorphic event that supplies the necessary heat and fluids to enhance the metassomatic reactions between the granitic and the ultramafic rocks. Since the plausible source of beryllium and fluorine are the postorogenic Borrachudos metagranites and pegmatites, the only younger tectonometamorphic event that could have been responsible for the deformation, metamorphism, and metassomatic reactions between the $\mathrm{Be} / \mathrm{F}$-bearing and the $\mathrm{Cr}$-bearing rocks was the $0.7-0.5 \mathrm{Ga}$ Neoproterozoic Brasiliano event, which is the last tectonothermal event registered in the region. The obtained $576 \pm 7 \mathrm{Ma}$ age of the dated titanite corroborates the interpretation that the Brasiliano event was indeed responsible for its generation.

We conclude thereafter that the $576 \pm 7 \mathrm{Ma}$ age of the fluorine-aluminum-bearing titanite of the metamafic rock associated with the emerald-mineralized phlogopite schists in the Piteiras mine from the Itabira-Nova Era Emerald District could also be the age of the emerald generation during the Neoproterozoic tectonometamorphic Brasiliano event. We suggest that the following geological processes were involved in the generation of the emerald deposits from the Itabira-Nova Era region:

1. Formation of the Volcanosedimentary Sequence (including Cr-bearing ultramafic rocks) of the Guanhães Complex during the Archean ( $-2.8 \mathrm{Ga})$.

2. Generation and metamorphism of the gneisses of the Mantiqueira Complex during the Paleoproterozoic Transamazonian event $(2.2-2.0 \mathrm{Ga})$ and intrusion of the late $1.7 \mathrm{Ga}$ anorogenic Borrachudos granite and their pegmatites.

3. Regional metamorphism during the Neoproterozoic and generation of the schist-type emerald mineralization by reactions between Be-bearing granites and pegmatites and Cr-rich metaultramafic rocks was enhanced by deformation and heat supplied by the tectonometamorphic Brasiliano event $(-0.7-0.5 \mathrm{Ga})$. The participation of hydrothermal fluids was crucial for the growth of emerald as well as for the phlogopitization of the ultramafic rock.

\section{ACKNOWLEDGMENTS}

Hanna Jordt-Evangelista acknowledges the support from FAPEMIG (APQ-00732-12). Cristiano Lana acknowledges the support from FAPEMIG (CRA 03943/10 and 067-10).

\section{REFERENCES}

Aleinikoff J.N., Wintsch R.P., Tollo R.P., Unruh D.M., Fanning C.M., Schmitz M.D. 2007. Ages and origins of rocks of Killingworth dome, South-Central Connecticut: Implications for the tectonic evolution of southern New England. American Journal of Sciences, 307(1):63-118

Alkmim F.F. \& Marshak S. 1998. Transamazonian orogeny in the Southern São Francisco Craton region, Minas Gerais, Brazil: evidence for Paleoproterozoic collision and collapse in the Quadrilátero Ferrífero. Precambrian Research, 90(1-2):29-58.

Almeida, F.F.M. 1977. O Cráton do São Francisco. Revista Brasileira de Geociências, 7:349-364.

Brito Neves B.B., Cordani U.G. 1991. Tectonic evolution of South America during the late Proterozoic. Precambrium Research, 53(1-2):23-40

Černý P. \& Povondra P. 1972. An Al, F-rich metamict titanite from Czechoslovakia. Neues Jahrbuch für Mineralogie Monatshefte, 400-406.

Chemale Jr. F. 1987. Gênese das rochas graníticas do tipo Borrachudos. In: Congresso Brasileiro de Geoquímica, 1. Anais..., 1:171-186.

Chemale Jr. F., Quade H., Van Schmus W.R. 1997. Petrography, geochemistry and geochronology of the Borrachudo and Santa Bárbara metagranites, Quadrilátero Ferrífero, Brazil. Zentralblatt für Geologie und Paläontologie, Teil I, 3(6):739-750.
Correia Neves J.M., Soares, A.C.P., Marciano, V.R.P.R.O. 1986. A Província Pegmatítica do Brasil à luz dos conhecimentos atuais. Revista Brasileira Geociências, 16(1):106-118

Delgado C.E.R. 2007. Geologia e petrogênese na região da Província Esmeraldífera de Itabira, MG. MS Dissertation, Departamento de Geologia, Universidade Federal de Ouro Preto, Ouro Preto, $130 \mathrm{p}$

Delgado C.E.R., Jordt-Evangelista H., Viana D.J. 2005. Grothita (titanita de Alto Al) da Província Esmeraldífera de Itabira, MG. In: 9 ○ Simpósio de Geologia do Sudeste e 13 Simpósio de Geologia de Minas Gerais. Anais..., p. 77.

Dorr J.V.N. 1969. Physiographic, stratigraphic and structural development of the Quadrilatero Ferrifero Minas Gerais, Brazil. U.S. Geological Survey. Washington, 110 p. (Professional Paper 641-A).

Dorr J.V.N. \& Barbosa, A.L.M. 1963. Geology and ore deposits of the Itabira District, Minas Gerais, Brazil. U.S. Geological Survey. Washington, 110 p. (Professional Paper 341-C).

Dossin I.A., Dossin T.M., Charvet J., Cocherie A., Rossi P. 1993. Singlezircon dating by step-wise Pb-evaporation of Middle Proterozoic magmatism in the Espinhaço Range, Southeastern São Francisco Craton (Minas Gerais, Brazil). In: Simpósio do Cráton do São Francisco, 2. Anais..., 39-42. 
Dussin T.M., Dussin I.A., Noce C.M., Rossi P., Charvet J. 1997. Tectonic setting and origin of the Mesoproterozoic Borrachudos granites (MG, Brazil). In: South-American Symposium on Isotope Geology, Campos do Jordão, Brazil. Extended Abstracts, 104-106.

Fernandes M.L.S., Marciano V.R.P.R.O., Oliveira R.C., Correia Neves J.M., Diláscio M.V. 1995. Granitos Borrachudos: um exemplo de granitogênese anorogênica na Porção Central do Estado de Minas Gerais. Geonomos, 2(2): 23-29.

Fernandes M.L.S., Pedrosa Soares A.C., Noce C.M., Widemann C., Correia Neves J.M. 2000. U-Pb geochronology of the Borrachudos Suite: Evidence of Brasiliano tectonism recorded by late Paleoproterozoic anorogenic granites (Araçuaí Belt, Minas Gerais, Brazil). In: International Geological Congress. Abstracts. CD-ROM, Abstract G1803074.

Franz G. \& Morteani G. 2002. Be-Minerals: Synthesis, stability, and occurrence in metamorphic rocks. In: Grew E.S. (ed.). Beryllium Mineralogy, Petrology, and Geochemistry. Reviews in Mineralogy and Petrology, 50(1):551-589.

Franz G., Gilg H.A., Grundmann G., Morteani, G. 1996. Metassomatism at a granitic pegmatite - Dunite contact in Galicia: the Franqueira occurrence of chrysoberyl (Alexandrite), Emerald, and Phenakite: discussion. Canadian Mineralogist, 34:1329-1331.

Gaines R.V., Skinner H.C.W., Foord E.E., Mason B., Rosenzweig A., King V.T., Dowty E. 1997. Titanite. In: Gaines R.V. et al. (eds.) Dana's New Mineralogy. New York, John Wiley, p. 1092-1094.

Gerdes A., Zeh A. 2006. Combined U-Pb and Hf isotope LA-(MC)ICP-MS analyses of detrital zircons: comparison with SHRIMP and new constraints for the provenance and age of an Armorican metasediment in Central Germany. Earth and Planetary Science Letters, 249(1-2):47-61.

Giuliani G., Silva L.J.H.D., Couto P. 1990. Origin of emerald deposits of Brazil. Mineralium Deposita, 25:57-64.

Grossi-Sad J.H., Chiod Filho C., Santos J.F., Magalhães, J.M.M., Carelos P.M. 1990. Duas suítes graníticas do bordo sudeste do Crátion Sanfranciscano em Minas Gerais: petroquímica e potencial metalogenético. In: SBG, Cong. Bras. Geol., 36, Natal, 1990. Anais, 4 1836-1848.

Grundmann G. \& Morteani G. 1989. Emerald mineralization during regional metamorphism: The Habachtal (Austria) and Leydsdorp (Transvaal, South Africa) deposits. Economic Geology, 84(7):1835-1849.

Heaman L.M. 2009. The application of U-Pb geochronology to mafic, ultramafic and alkaline rocks: an evaluation of three mineral standards. Chemical Geology, 261(1-2):42-51

Jordt-Evangelista H., César-Mendes J., Lima A.L.C. 2000. Amazonitização em granito resultante da intrusão de pegmatitos. Revista Brasileira de Geociências, 30(4):693-698

Ludwig K.R. 2012. Isoplot/Ex Version 3.75: A Geochronological toolkit for Microsoft Excel. Berkeley, CA, Berkeley Geochronology Center Special Publication 5, $72 \mathrm{p}$

Machado G.A.A. 1994. Geologia da região e aspectos genéticos das jazidas de esmeralda de Capoeirana e Belmont, Nova Era - Itabira, MG. MS Dissertation, Instituto de Geociências, Universidade de São Paulo, São Paulo, 134 p.

Machado G.A.A. 1998. Jazidas de esmeralda de Capoeirana e Belmont - MG: Geologia, petrogênese e metalogênese. PhD Thesis, Instituto de Geociências, Universidade de São Paulo, São Paulo, 294 p.

Morteani G., Preinfalk C., Horn A.H. 2000. Classification and mineralization potential of the pegmatites of the Eastern Brasilian Pegmatite Province. Mineralium Deposita, 35:638-655.
Netto C., Araújo M.C., Pinto C.P. Drumond J.B.V. 1998. Projeto Leste- Programa Levantamentos Geológicos Básicos do Brasil - Cadastramento de Recursos Minerais. Província Pegmatítica Oriental. Mapeamento Geológico e Cadastramento de Recursos Minerais da Região Leste de Minas Gerais, Belo Horizonte, CPRM, 105 p. (Relatório Final).

Padilha A.V., Vieira V.S., Bruno E.M. 2000. Programa Levantamentos Geológicos Básicos do Brasil; Carta Geológica, Carta Metalogenética/ Previsional - Escala 1:100.000 (Folha SE.23-Z-D-IV Itabira) Estado de Minas Gerais. Brasília, DNPM/CPRM. Mapa e texto explicativo.

Paiva G. 1946. Províncias Pegmatíticas do Brasil. DNPM/DFPM, Boletim 78, p. 13-21

Peres G.G., Alkmim F.F., Jordt-Evangelista H. 2004. The Southern Araçuaí Belt and the Dom Silvério Group: geologic architecture and tectonic significance. Anais da Academia Brasileira de Ciências, 76(4):771-790

Preinfalk C., Kostitsyn Y., Morteani G. 2002. The pegmatites of the Nova Era-Itabira-Ferros pegmatite district and the emerald mineralisation of Capoeirana and Belmont (Minas Gerais, Brazil): Geochemistry and Rb-Sr dating. Journal of South American Earth Sciences, 14(8):867-887.

Ribeiro P.A. 2006. Geologia e controle estrutural dos corpos mineralizados em esmeraldas do Garimpo de Capoeirana, Nova Era/MG. MS Dissertation, Departamento de Geologia, Universidade Federal de Ouro Preto, Ouro Preto, 128 p.

Ribeiro-Althoff A.M., Cheilletz A., Giuliani G., Féraud G., BarbosaCamacho G., Zimmermann J.L. 1997. ${ }^{40} \mathrm{Ar} /{ }^{39} \mathrm{Ar}$ and $\mathrm{K}-\mathrm{Ar}$ geochronological evidence for two periods ( 2 Ga and 650 to 500 $\mathrm{Ma}$ ) of emerald formation in Brazil. International Geology Review. 39(10):924-937.

Schorscher H.D. 1991. Quadrilátero Ferrífero e Espinhaço Meridional. In: 30 Congresso Brasileiro Geoquímica. São Paulo, Guia de Excursão, p. 37-87.

Schwarz D. \& Giuliani G. 2001. Emerald deposits - a review. Australian Gemologist, 21:17-23.

Schwarz, D., Giuliani, G., Grundman, G., Glass, M. 2002. The origin of emerald. In: Emeralds of the World, extraLapis English, 2: 18-23.

Silva L.C., Armstrong R. Noce C.M., Carneiro M.A., Pimentel M., Pedrosa-Soares A.C., Leite C.A., Vieira V.S., Silva M.A., Paes V.J.C., Cardoso Filho J.M. 2002. Reavaliação da evolução geológica em terrenos pré-cambrianos brasileiros com base em novos dados U-Pb SHRIMP, Parte II: Orógeno Araçuaí, Cinturão Mineiro e Cráton São Francisco Meridional. Revista Brasileira de Geociências, 32(4):513-528

Souza J.L. 1988. Mineralogia e geologia da esmeralda da Jazida de Itabira - Minas Gerais. MS Dissertation, Instituto de Geociências, Universidade de São Paulo, São Paulo, 192 p.

Souza J.L., César-Mendes J., Bello R M S., Svisero D.P., Valarelli J.V. 1992. Petrographic and microthermometrical studies of emeralds in the garimpo de Capoeirana, Nova Era, Minas Gerais State, Brazil. Mineralium Deposita, 27(2):161-168

Viana D.J. 2004. Geologia e petrogênese da jazida de esmeralda de Piteiras, MG. MS Dissertation, Departamento de Geologia, Universidade Federal de Ouro Preto, Ouro Preto, 220 p.

Viana D.J., Jordt-Evangelista H., Souza Gomes C. 2006. Esmeralda da Mina de Piteiras, região de Itabira, MG: geologia e gênese. Revista Brasileira de Geociências, 36: 174-178.

Available at www.sbgeo.org.br 